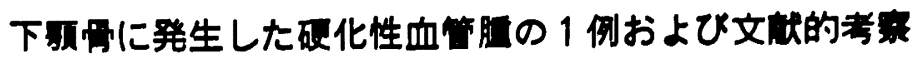

\author{
饭家不弮・俔家和男・風本和己

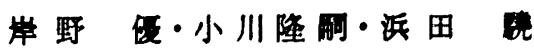

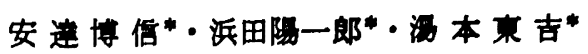

\section{A case of sclerosing hemangioma in the mandibular bone and its review of the literature}

\author{
Hitomi Ryoke - Kazuo Ryoke - Kazumi Oxamoto \\ Masaru Krshino - Takaaki Oonwa - Takeshi Hamada \\ Hironobu AdAchi* - Yoichiro Hamada* - Tokichi Yusoto*
}

\begin{abstract}
Sclerosing hemangioma was formerly considered as hemangioma with fibrous vegetation. But recently this lesion has been believed to belong to subepidermal nodular fibromatosis which is a subtype of fibrous histiocytoma. The histological characteristic of are that many spindle cells and fine fibers present a specific storiform pattern with the arrangements around capillary nets.

The lesions have been rarely reported in maxillofacial region. We recently encontered a mandibular bone case histopathologically diagnosed as sclerosing hemangioma. The patient was a 47-year-old Japanese male who was initially examined in our hospital May 14, 1985 with a chief complaint of painless swelling in the left side of buccal mucosa region, and pre- and infraauricular region. In extraoral findings about $6 \times 6 \mathrm{~cm}$ of apparently circumscribed swelling was found in the left side of pre- and infraauricular region, which was painleas and elastic hard in consistency. There were not reddish spots and no sensation abnormalities such as hypesthesia on the surface of the mass.

In intraoral findings about $3 \times 3.5 \mathrm{~cm}$ of diffuse swelling from the left side of buccal mucosa region to the glosso-palatine arch, which was elastic soft in consistency and indolent, was revealed.

Some radiographs showed an apparently well-defined radiolucency in most of the left mandibular ascending ramus. The tumor was extirpated in a mass intraorally under general anesthesia. Histopathological examination with hematoxylin-cosin stain, PAS stain, silver stain and Masson stain and immunohistological examination were carried out. Consequently this lesion was diagnosed as sclerosing hemangioma. Further review of the literature on this lesion was done.
\end{abstract}

Key words: sclerosing hemangioma, fibrous histiocytoma, storiform pattern

鳥取大学医学部科口腔外科学数室

（主任：浜田莲教授）

* 鳥取大学医学部病理学第 1 数室

(主任：湯本東吉教授)

Deparment of Oral and Maxillofacial Surgery,

Tottori University School of Medicine (Chief:
Prof. Takeshi Hamada)

* Department of Pathology, Tottori University School of Medicine (Chief: Prof. Tokichi Yumoto)

受付日：昭和63年 3 月11日 


\section{啨}

硬化性血管腫 (Sclerosing hemangioma) は，1943 年 Gross ら" により初めて記誡され，当初は血管陣に線䊒 性増殖が起こったすのと考克られていた。

しかしながら，1967年 Stout ${ }^{23}$ は，これを線稚性組峨 球腫 (fibrous histiocytoma) の一亜型である表皮下結節 性線䊒症 (subepidermal nodular fibrosis) K属するるの

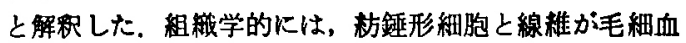
管散を中心に配列し，特異な storiform pattern を星す るのが特徵とされており，口腔領域での報告は非常にま れな疾患である。

最近, 著者らは下影骨に発生し，組傤学的に硬化性血

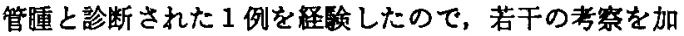
えてその概要を報告する。

\section{症例}

恵 者： 47歳 男性.

初 猃: 昭和 60 年 5 月回。

主 訴：左側頓粘膜部および耳介前部から耳介下部へ の無痛性腫脹。

既往歴：30歳の時, 腰椎すべり症の手術を受けてい る.

家族歴：特記すべき事項なし。

現病歴：当科初部の約 1 年前に, 左側煩粘膜の腫脹に 気付くとともに，その頃より左㑡煩部をよく咬むように なった，その後，同部の畽脹は徐々に增大㑯向を示した が，無痛性のため放置していた，約 3 か月前より，左側 耳介前部から耳介下部にかけて，無痛性腫脹を認めるよ らになったため，某歯科を受診。歯原性炎症の診断下 に, $\sqrt{7}$ の感染根管治㞠を受けたが腫脹の改善がるられな いため，当科を紹介され来院。

現 症：全身所見では，体格中等度，栄盖状態良好で あり, 特記すべき事項なし.

口腔外所見：左側耳介前部から耳年下部にかけて，約 $6 \times 6 \mathrm{~cm}$ の比較的限局 した弾性硬で無痛性の腫脹を認 めた，表面皮店に恃発赤や知覚低下などの異常は認めな かった，左側額下リンバ節は，小指頭大に腫脹し，弾性 硬，可動性であったか，殴痛は認めなかった，右側顥下 リンパ節はェンドウ大に腫脹し，弾性硬，可動性であ り，王痛は認めなかった（写真 1，2）。

口腔内所見：左側煩粘膜から口蓋舌弓にかけて，約 $3 \times 3.5 \mathrm{~cm}$ のび漫性で，弾性軟，無痛性の重脹を認め た. 表面粘膜は一部咬傷による瘢痕様の白色病変がみら れたが，その他には異常は認められなかった(写柤了)。 左側耳下腺乳頭からの㗆液の分泌は, 右側に比較して若 干低下傾向が認められた. $\sqrt{7}$ を含めて菌牙には何ら異常

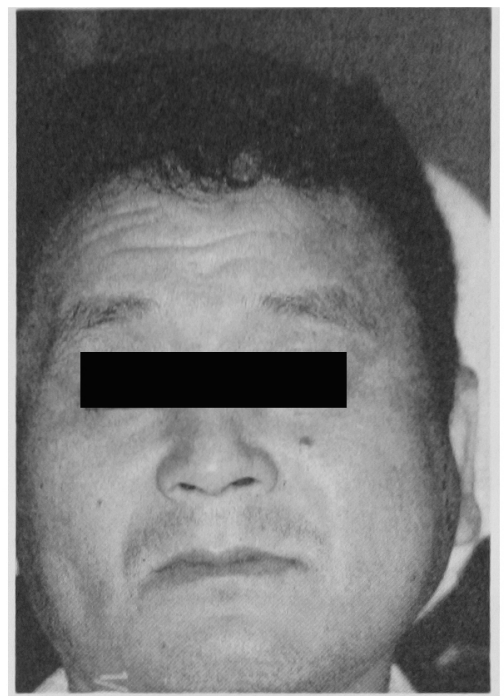

写真 1 初朗時の願貌写真

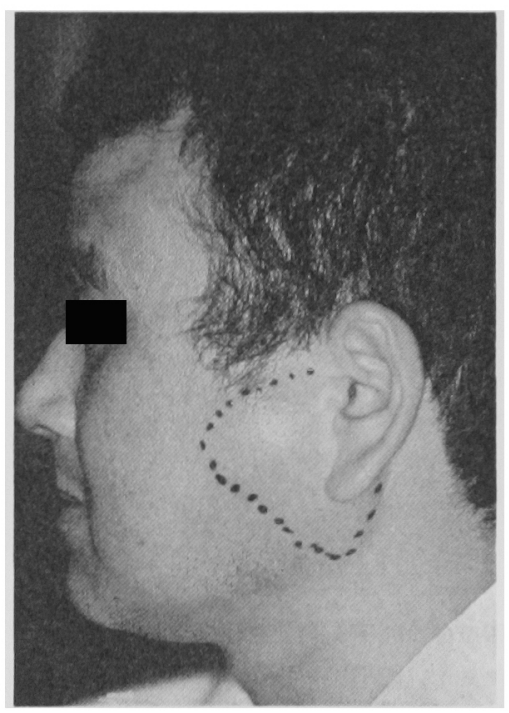

写真 2 初晾時の㑡貌写真

は認めなかった。

$\mathbf{X}$ 線所見：顔面正面撮影，ハノラマ撮影，下影枝断層 撮影にて，左側下频枝の大部分を占める，比較的境界明 瞭なX線透過像を認めた（写真 4 6). 左側耳下腺造影 所見においては，何ら異常は諗められなかった。

臨床診断：下顎骨良性腫瘍の疑い。

処置および経過：昭和61年 5 月曰日，局所麻醉下にて 口内法により試験切除を施行した。病理組織学的所見に 扣いて，神経原性腫湯または線維性組織球弫が疑われ， 確定診断に至らなかった，そこで，創部の治窟を確認 


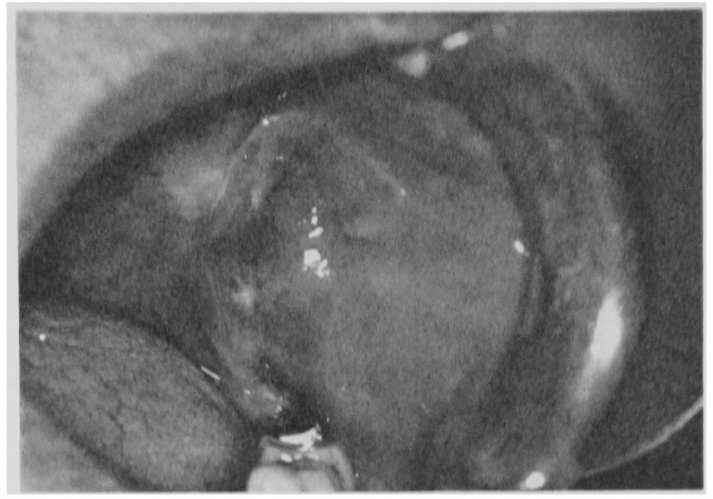

军克 3 口悾内军真

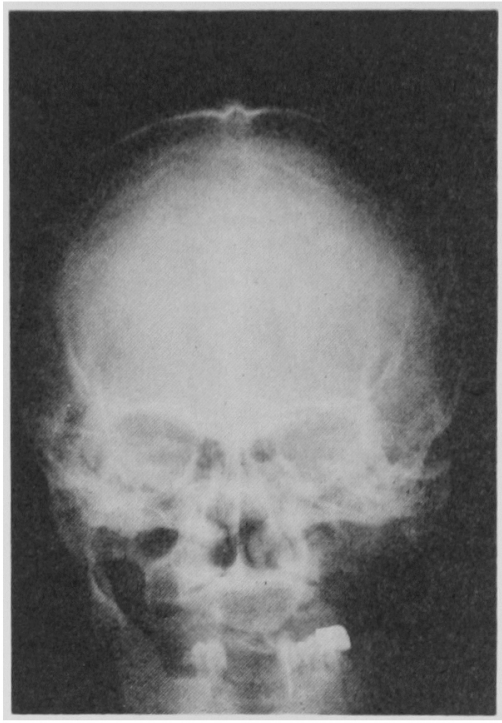

写率 4 顔面正面X線写真

後，7月日日診断確定の目的で当科に入院した，各種臨 床検查成績においては，呼吸機能検査で軽度の閉塞性換 気障害と動脈血ガス分析て $\mathrm{PO}_{2}$ の軽度低下がみられた 以外，特に異常は認められなかった（表 1)，7月回， 全身麻酔下にて再度試験切除を試みたところ，腫場は充 実珄で比較的硬く，被膜に被われて境界明暸であったた め，淮徒手的に一塊として摘出できた，腫痬は，下䫑

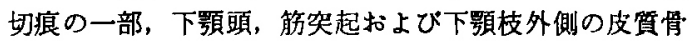
を䔦く残すのみで，下買枝の大部分を占めていた。一 方，舌側に特いては口底から口蓋舌弓方向人多房性に増 殖していた，下額神経血管束は，下顎骨底部でやや舌側 に位置し，腫瘤とは比較的容易に剝離できた（写事 7). 摘出後創部に抗生物質軟膏を筮布したガーゼを王迫扦入 した，その後創面の上皮化は順調にすすみ，経過良好の ため 7 月日退院した。

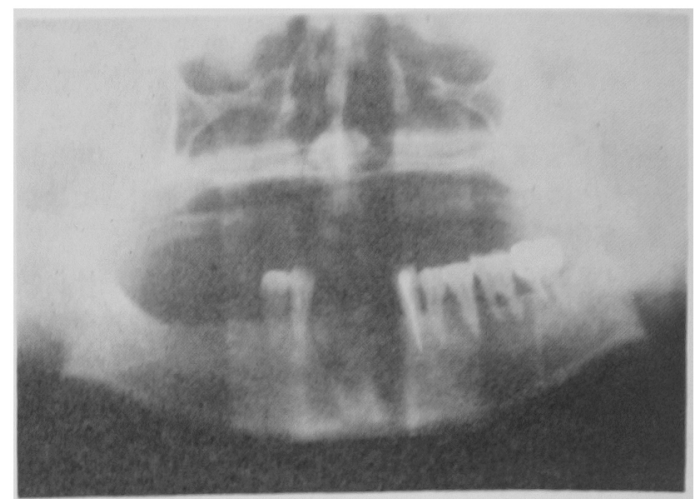

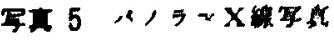

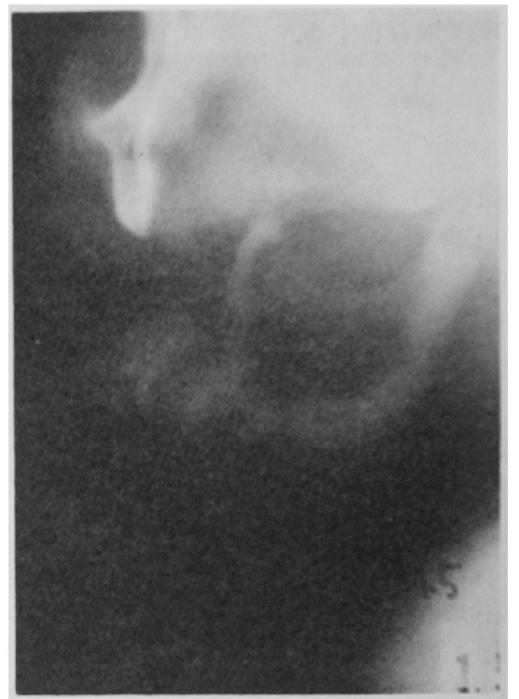

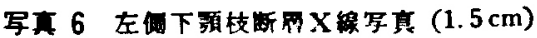

摘出物所見：睡溜は $5.5 \times 5.5 \times 4.0 \mathrm{~cm}$ の大きさで， その表面は大小さまさまな結節状で出不整を呈してい た．硬度は汪注一様に弾性㣏であった，表面は黄白色を 呈し，薄い被膜に被われていた，割面においてては，充実 性ではあるが们均一な性状を示し，色調においても辺彎 は灰赤色を呈しているのに対して，中心の大部分は黄白 色を呈していた，一部、被脱の穿孔と組維の挫牫が認め られたか，前回の試検切除の医に加えられた損賃と考光 られた（写矛 8，9）。

病理組满学的所見：へマトキシリン・エオジン染色票 本においては，周辺部は毛細血管増生とその間を埋める ように類円形ないしし紡矮形の組維球様細胞が增生が認め られたのに対して，中心部は練胞成分は少なく硝子化が 著明であった，細胞增生の密な部分では腫煌細胞の流れ がみられ， storiform pattern に類似した像を呈していた 


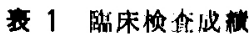

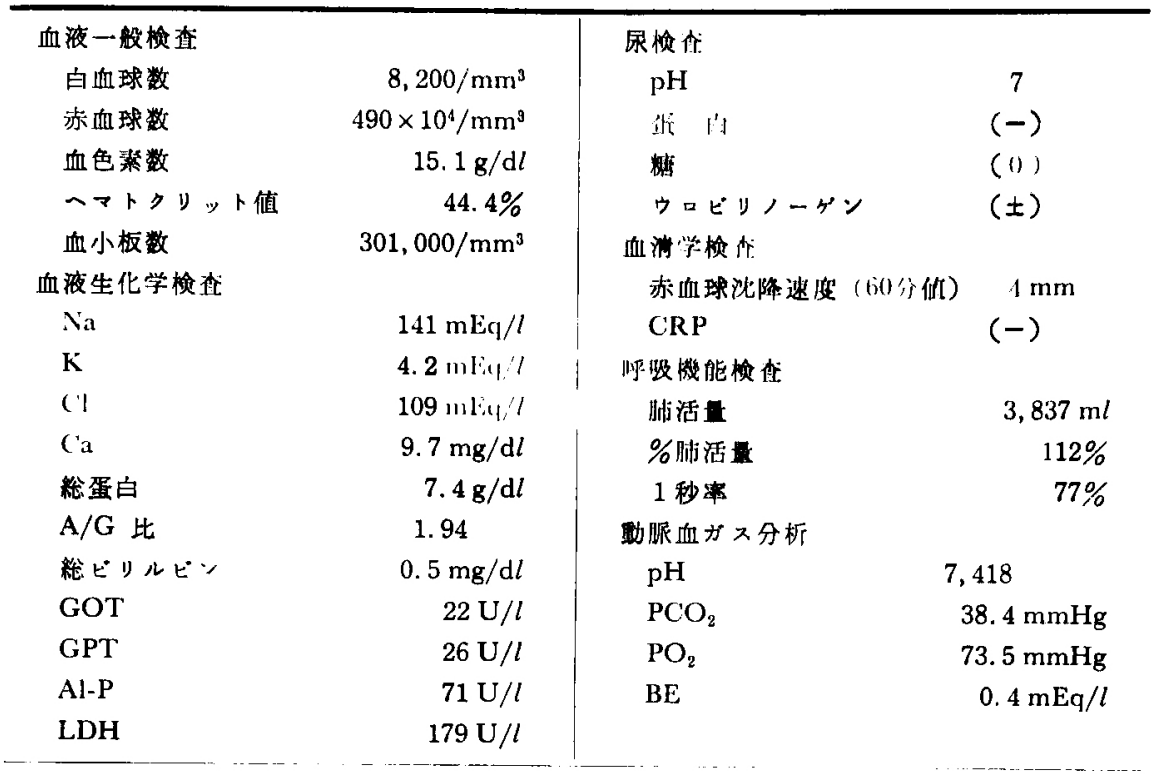

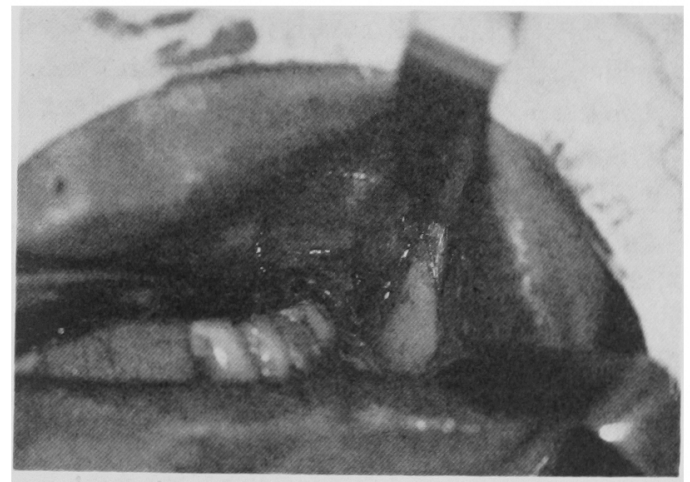

写真 7 手術時所見

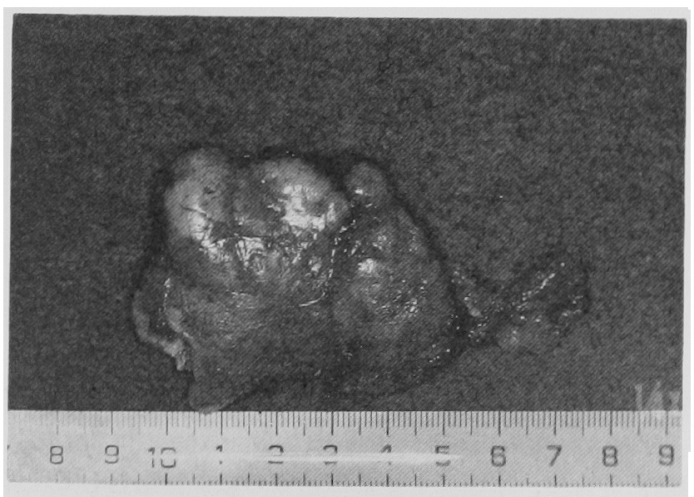

写真 8 摘出物所見 一部切除している

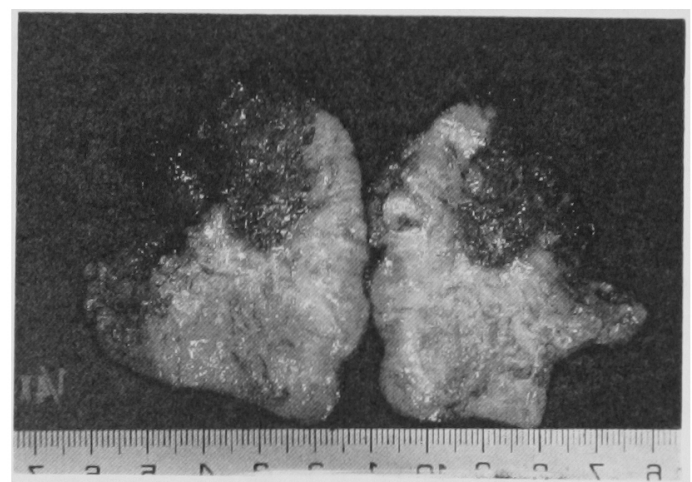

写育 9 摘出物の剖面

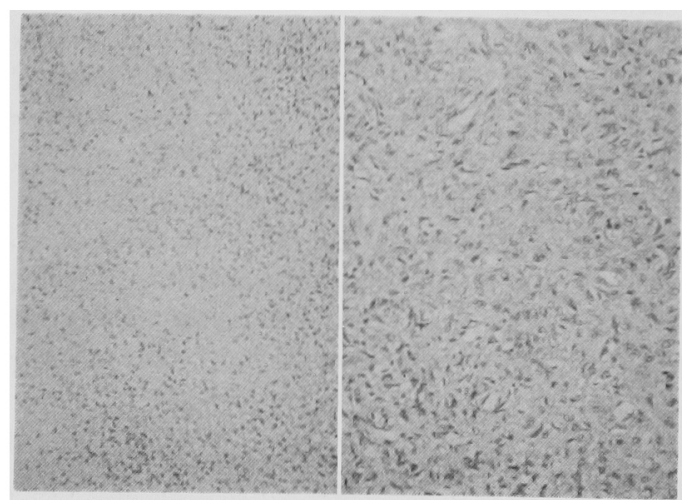

写真 10 病理組織像 (H-E 染色)

左は中心部，右は周辺部 


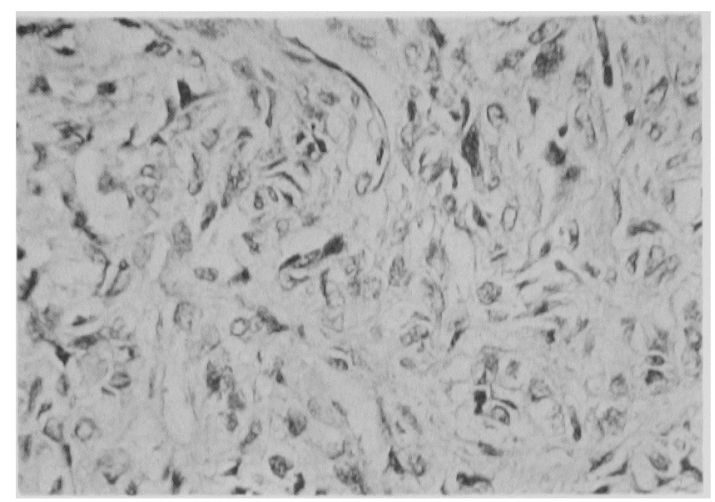

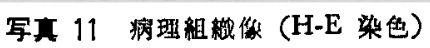
周辺部の強坛大

（写重 10，11）。

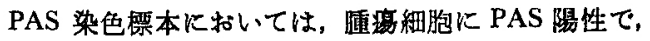
しかもジスターゼで消化される小顆精が多数認められ た.

マッソン染色標本では，硝子化した部分が陽性を示し た (写真 12 の左).

鍍銀染色漂本では，睡晹細胞の多い部分で好銀線維が 紐胞を取り囲んでいる像が認められた（写真12の右）.

睡湯細胞の核分裂像や細胞の巽型性など，墨性像を思 わせる所見は認められなかった。

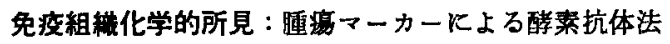
を行ったところ、ライソザイム， $\alpha_{1}$-アンチキきトリブ シン, 第壮因子関連抗原に批いては陽性, S-100 蛋白は 陰性の結果が得られた。

病理組機学的診断：硬化性血管腯 (Sclerosing hemangioma).

考察

硬化性血管睡の報告は，1943 年 Gross ら 初めて記載され，その本体は血管腫に線維性增殖が起こ ったものと考えられていた。 1971 年 Colby ら ${ }^{3)}$ す血管 畽を組䅧学的飞 capillary type, cavernous type, sclerosing type K分類し, やはり本疾患を 血管睡の一型と みなしている。一方，1965年 Shklar and Meyer')は。 血管腫がたとえ外傷や感染などをこらむらなくても，し ばしば硬化の過程をたどることを指摘し，硬化性血管腫 Кついてふれている，Friedlander ${ }^{53}$ は54藏白人男性の舌 背部に生した 1 例を，Stafford ${ }^{6)}$ は25歳マレーシア人女 性の頸部に生した硬化性血管腫の1例を報告している.

本邦において，口腔領域に発生した硬化性血管腫の報 告として，その本体を血管腫とするるのに，1975年出崎 らフが報告した 76 歳男性の煩粘膜上に生じた 1 例と,

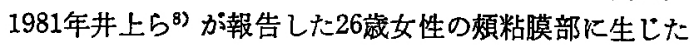

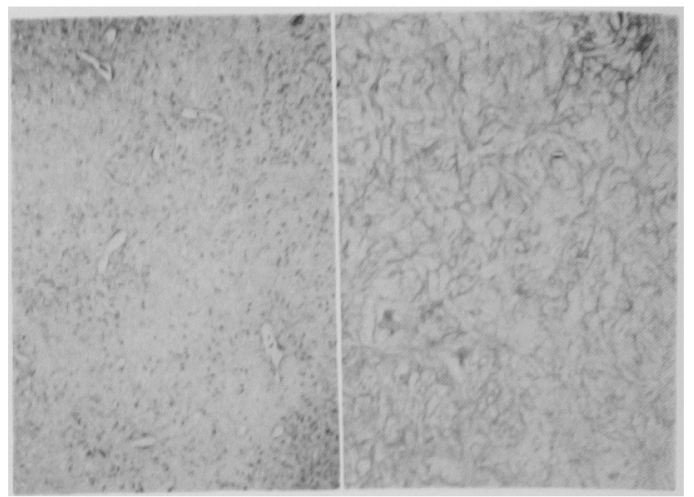

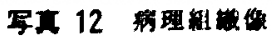

左はマッンン架色，右は慨架色

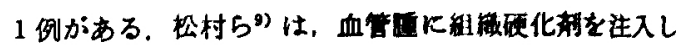

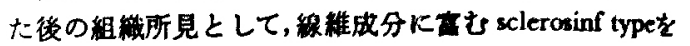
珰めたことを㫰告し，硬化性血等便の存在を支持してい る，以上の報告は，いナ゙れるそれぞれの組㯕像の表現に 多少の差異はあるるのの, 病变の本慜あるい、恃成因下関 する考え方として，本在患は本筫的には血管便であり， それに何らかの硬化要因ないし硬化行程が加わって生し た一㮔の退行性病变であるといら解积がなされている。

しかしながら，1967年 Stout and Lattes2) はこのよう

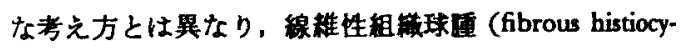
toma）の vascular variant と解规している. すなから，

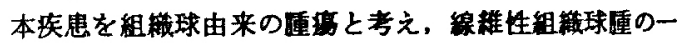
西型である表皮化結節性線㱷庭 (subepidermal nodular fibrosis）に属するるのとみなした．これと同様の考方方 に基づいて報告している人たちる多い(10-15)これらの

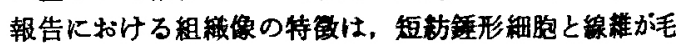
細血管絧を中心に，マット状下密に卧列し，いわする storiform patternを呈する像とされている。すた，脂質

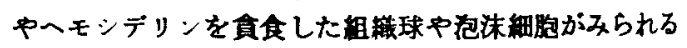

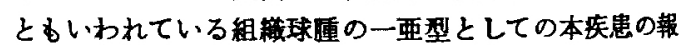

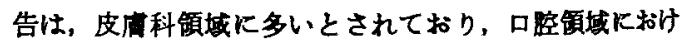

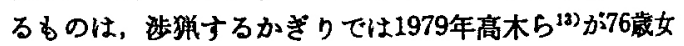
性の䫅粘膜に生じた1例をみるのみである. 高木らはそ

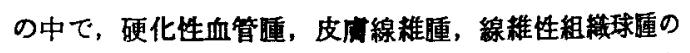
3つの閣に倸いて，その本質には検討の余地があると 述へている。

今回の著者らの症例は，かつて本那において報告をみ ない下顎骨に発生しており，組笧学的所見においてて出 畸ら7，井上ら の報告とは槏相を異にしている。

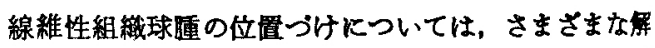
釈がある. 湯本 ${ }^{11,12)}$ によると，Stout and Lattes の見 解に從って，本睡場を組織球由来の軟部隀䔾として理解 している．図1に示すよらに，組織球から泡洙紏胞ある いは線維形成への分化の方向があり, 組織球增生を主体 


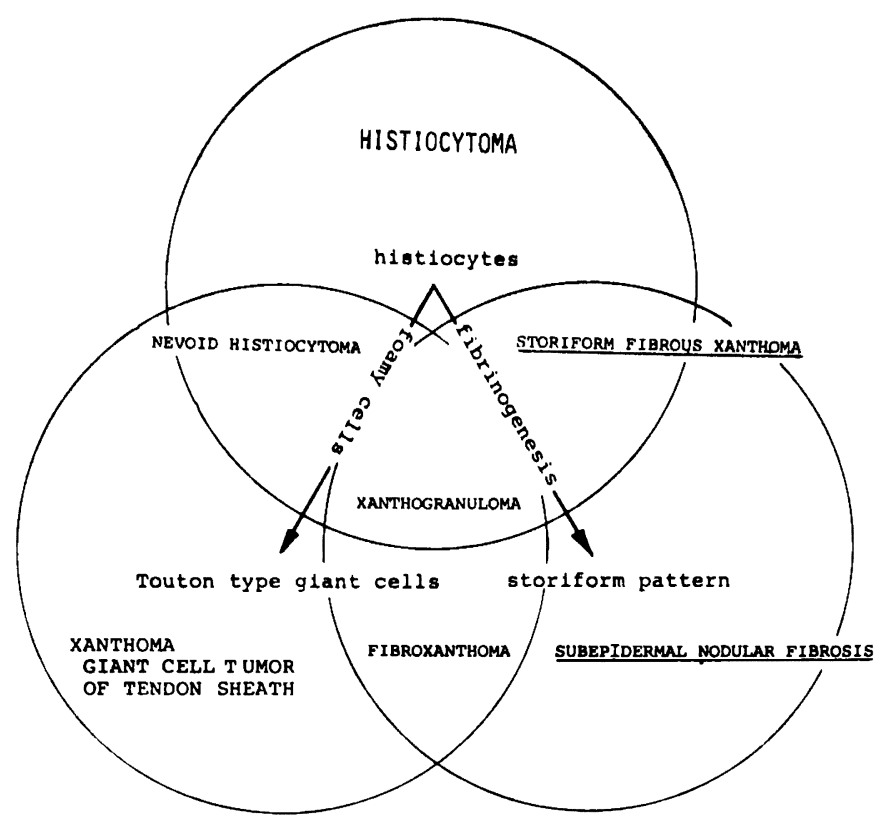

图 1 Fibrous histiocytoma の各型の相网网保を示す模式图

（晹本東吉：踇整外，8，698-713，1973より利用）

とするるのが組䄉球腫であり，線維形成を主体とするす のが表皮下結節性線䊒症であり，泡沫細胞の増殖を主体 とするるのが黄色畽であるとしている，従来，硬化性血 管隀は, 皮庙線稚匭 (dermatofibroma) と同義語として 使用されるなど，表皮下結節性線維症の中に入れられて

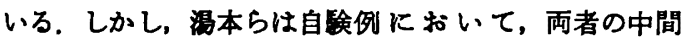
型，移行型は見出せなかったことから，Rentiers and Montgomery ら ${ }^{16)}$ の主張に從い，2つの重晹をそれぞれ 独立したるのと考えている。 むしろ，多数例の検討の結 果, 組織学的には硬化性血管董は，花むしろ状線維性黄 色腫 (storiform fibrous xanthoma) と区別できない場 合がしばしばあることを指摘し，硬化性血管腫は花むし ろ状線椎性黄色畽の初期像として理解されるるのと主張 している.

本症例の組織学的所見は，毛細血管の増生と，それを 埋めるように短紀鏵形の組織球侎細胞增生がみられ, storiform pattern に類似した像を呈していたことより， 晹本の見解に従い硬化性血管腫之診断した。しかし，湯

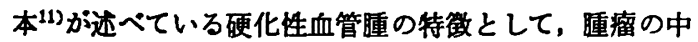
心部と辺㟤部ではその組織像に著しい差異がないとして いるが，本症例の場合，中心部は細胞成分が少なく，硝 子化が著明であり，これ性疗線䑾腫の特徽に一政する すのである．このように組織学的特致だけでなく，組織 由来あるいは分類上において，若干の問題点は残り，今 後の検討が必要である。
結語

著者らは，47歳の男性の下䫓骨に生じた硬化性血管腫 の 1 例を経検したので報告した。

\section{引用文 献}

1) Gross, R.E. and Wolbach, S.B.: Sclerosing Hemangiomas; Their Relationship to Dermatofibroma, Histiocytoma, Xanthoma and to Certain Pigmented Lesions of the Skin. Am J Pathol 19: 533-551 1943.

2) Stout, A.P. and Lattes, R.: Tumors of the soft tissues. In Atlas of Tumor Pathology. fasc. I, Armed Forces Insitute of Pathology, Washington, 1967, p 38-52.

3) Colby, R.A., Kerry, D.A., et al.: Color Atlas of Oral Pathology. 3 rd Ed, Lippincott Co, Philadelphia, 1971, p 144.

4) Shklar, G. and Meyer, I.: Vascular tumors of the mouth and jaws. OS OM OP 19: 3353581965.

5) Friedlander, A.H. and Zeff, S.: Sclerosing hemangioma of the tongue: report of case. J Oral Surg 33: 212-214 1975.

6) Stafford, N.D.: A sclerosing haemangioma in 
the neck. J Laryngol Otol 95: 1173-1177 1981.

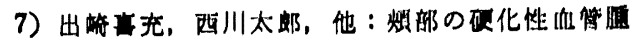

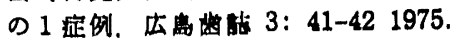

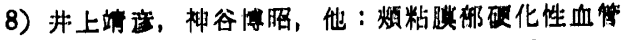
婳の 1 例. 日口外声 27：1479-1481 1981.

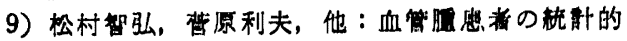

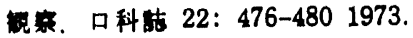

10) Robbins, S.L.: Pathologic basis of disease. Saunders Co, Philadelphia, 1974, p 629-630.

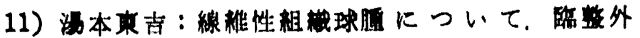
8: 698-713 1973.

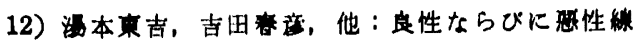

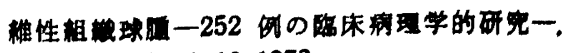
米子医 29: 1-12 1978.

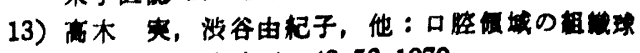

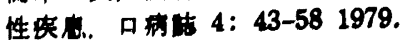

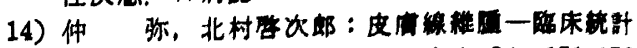

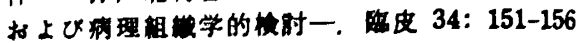
1980.

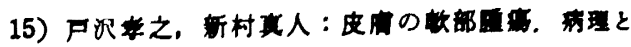
踽床 2: 817-818 1984.

16) Rentiers, P.L. and Montgomery, H.: Nodular Subepidermal Fibrosis (Dermatofibroma versus Histiocytoma). Arch Dermatol Syph 59: 5685831949. 